\title{
Indole-6-carboxaldehyde isolated from Sargassum thunbergii inhibits the expression and secretion of matrix metalloproteinase-9
}

\author{
TAE-HEE KIM ${ }^{1,2^{*}}$, SOO-JIN HEO ${ }^{3,4^{*}}$, SEOK-CHUN KO $^{5}$, WON SUN PARK ${ }^{6}$,

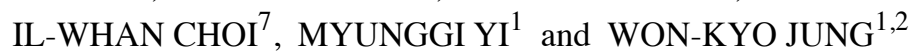 \\ ${ }^{1}$ Department of Biomedical Engineering, and Center for Marine-Integrated Biomedical Technology (BK21 Plus), \\ ${ }^{2}$ Marine-Integrated Bionics Research Center, Pukyong National University, Busan 48513; \\ ${ }^{3}$ Jeju International Marine Science Center for Research and Education, Korea Institute of Ocean Science and Technology, \\ Jeju 63349; ${ }^{4}$ Department of Biology, University of Science and Technology, Daejeon, South Chungcheong 34113; \\ ${ }^{5}$ National Marine Bio-Resources and Information Center, National Marine Biodiversity Institute of Korea, Seochun, \\ Chungcheongnam 33662; ${ }^{6}$ Department of Physiology, Kangwon National University School of Medicine, Chuncheon, \\ Gangwon 24341; ${ }^{7}$ Department of Microbiology, College of Medicine, Inje University, Busan 47392, Republic of Korea
}

Received December 31, 2018; Accepted July 16, 2019

DOI: $10.3892 / \mathrm{ijmm} .2019 .4319$

\begin{abstract}
Sargassum thunbergii is a brown alga from which various bioactive compounds can be extracted. Among these, the activities of indole derivatives, particularly as potential inhibitors of matrix metalloproteinases (MMPs), and their underlying mechanisms have been rarely investigated. Therefore, we evaluated the inhibitory effects of indole-6-carboxaldehyde (I6CA) on MMP-9 by gelatin zymography and western blot anlaysis. We used phorbol 12-myristate 13-acetate (PMA), which is known to induce MMP-9 expression and secretion, to stimulate HT1080 cells. Our results revealed that I6CA significantly inhibited MMP-9 expression and secretion, without significantly affecting the viability of PMA-stimulated HT1080 cells. Our mechanistic studies indicated that I6CA suppressed the phosphorylation and activation of two mitogen-activated protein kinases (MAPKs), c-Jun $\mathrm{N}$-terminal kinase (JNK) and extracellular signal-regulated kinase 1/2 (ERK). Furthermore, I6CA inhibited the phosphorylation of inhibitor of $\kappa \mathrm{B} \alpha(\mathrm{I} \kappa \mathrm{B} \alpha)$ in response to PMA stimulation, which suppressed nuclear factor- $\kappa \mathrm{B}(\mathrm{NF}-\kappa \mathrm{B})$ p65 subunit nuclear translocation. Collectively, I6CA was determined to suppress MMP-9 expression and secretion, and
\end{abstract}

Correspondence to: Professor Won-Kyo Jung, Department of Biomedical Engineering, and Center for Marine-Integrated Biomedical Technology (BK21 Plus), Pukyong National University, 45 Yongso-ro, Busan 48513, Republic of Korea

E-mail: wkjung@pknu.ac.kr

${ }^{*}$ Contributed equally

Key words: Sargassum thunbergii, indole-6-carboxaldehyde, matrix metalloproteinase-9 (MMP-9), mitogen-activated protein kinases, nuclear factor- $\kappa \mathrm{B}$ effects were proposed to be mediated via the inhibition of the MAPK and NF- $\kappa$ B p65 pathways. Therefore, we suggested I6CA to be a potential therapeutic agent for MMP-9-related processes, including tumor invasion and metastasis; however, further investigation is required.

\section{Introduction}

The degradation of the extracellular matrix (ECM) serves an important in various diseases; for instance, in cancer, ECM degradation contributes to tumor invasion or metastasis (1). The matrix metalloproteinases (MMPs) are important members of the zinc-dependent endopeptidase family and have been classified into eight subgroups, which include collagenases, matrilysin, metalloelastase, gelatinases, enamelysin and stromelysins (2). These enzymes target several components of the ECM, such as collagen, elastin and fibronectin; thus, they serve a crucial role in its degradation (3). In addition, MMPs are involved in a variety of physiological and pathological processes, including angiogenesis, tissue remodeling, and tumor invasion and metastasis (4-6). Among the MMPs, MMP-2 and MMP-9 are gelatinases, and have been reported to serve an important role in tumor invasion and metastasis through their ability to degrade an essential ECM component, type IV collagen (7). Notably, previous reports have established that the increased MMP-9 expression in cancer cells is associated with a marked increase in tumor invasion and metastasis, which is mediated by ECM degradation (8-10). Therefore, the targeted inhibition of MMP-9 expression in cancer cells presents a promising approach to suppress ECM degradation, and restrain tumor invasion and metastasis $(1,11,12)$.

Brown algae constitute a rich source of bioactive compounds, which have recently attracted increasing attention due to their biomedical and pharmaceutical potential $(13,14)$. As of the health-beneficial effects of these bioactive compounds, brown algae have been used worldwide, including Korea, Japan, China, and European countries, as a functional 
food, medicinal ingredients and gelling agents $(15,16)$. Among brown algae, Sargassum thunbergii is one of the main species in biomass, as well as an important pharmaceutical resource $(17,18)$. Accordingly, extracts and bioactive compounds, including polysaccharides, phlorotannins, flavonoids and proteins, which are derived from $S$. thunbergii have been extensively investigated (18). Furthermore, numerous studies demonstrated that these extracts and compounds exhibit a broad spectrum of biological activities, including pro-osteoblastogenic, antitumor, anti-inflammatory, antioxidative, anti-MMP and anti-adipogenic effects (19-28).

Indole derivatives can be produced through chemical synthesis or can be isolated from several natural resources, including Actinobacteria, algae, cruciferous vegetables, fungal and marine sponges (29-32). They exhibit a variety of biological activities, including antitumor, antioxidative, anti-inflammatory and anticonvulsant properties (33-35). In addition, the indole derivative indole-6-carboxaldehyde (I6CA) has been shown to exert anti-adipogenic effects in 3T3-L1 adipocytes (26). Although previous reports have highlighted their biological potential, to the best of our knowledge, no study has reported the MMP inhibitory activity of indole derivatives and their underlying mechanism of action.

Therefore, the present study aimed to utilize phorbol 12-myristate 13-acetate (PMA), a compound that can activate MMP-9, to mimic the conditions in cancer cells, and investigate the inhibitory effects of I6CA isolated from $S$. thunbergii on MMP-9. Furthermore, we aimed to determine the mechanism underlying the effects of I6CA in HT1080 cells.

\section{Materials and methods}

Materials. The brown alga $S$. thunbergii was collected from the coast of Jeju Island, Korea. The HT1080 cell line was obtained from the American Type Culture Collection. Dulbecco's modified Eagle's medium (DMEM), fetal bovine serum (FBS), penicillin/streptomycin/amphotericin (10,000 U/ml, 10,000 $\mu \mathrm{g} / \mathrm{ml}$, and 2,500 $\mu \mathrm{g} / \mathrm{ml}$, respectively), phosphate-buffered saline (PBS), and $0.25 \%$ trypsin-ethylenediaminetetraacetic acid (EDTA) were purchased from Invitrogen (Thermo Fisher Scientific, Inc.). 3-(4,5-dimethylthiazol-2-yl)-2,5-diphenyltetrazolium bromide (MTT), gelatin (type A), PMA, dimethyl sulfoxide (DMSO) and silica gel were purchased from Sigma-Aldrich (Merck KGaA).

The specific anti-MMP-9 rabbit polyclonal antibody (ab38898) was purchased from Abcam. Rabbit polyclonal antibodies against extracellular signal-regulated kinase (ERK) 1/2 (sc-292838), p38 (sc-7149), and glyceraldehyde 3-phosphate dehydrogenase (GAPDH; sc-25778), mouse monoclonal antibodies against phosphorylated (p)-ERK 1/2 (sc-7383), c-Jun N-terminal kinase (JNK) 1/2 (sc-7345), p-JNK 1/2 (sc-6254), p-p38 (sc-7973), and nuclear factor- $\kappa \mathrm{B}(\mathrm{NF}-\kappa \mathrm{B})$ p65 (sc-8008), and horseradish peroxidase-conjugated donkey polyclonal secondary antibody against goat IgG (sc-2020) and goat polyclonal secondary antibody against mouse IgG (sc-2031) were all purchased from Santa Cruz Biotechnology, Inc. The anti-inhibitor of NF- $\kappa \mathrm{B} \alpha(\mathrm{I} \kappa \mathrm{B} \alpha)$ rabbit polyclonal (cat. no. 9242) and anti-p-I $\mathrm{B} \alpha$ rabbit monoclonal (cat. no. 2859) antibodies were purchased from Cell Signaling Technology, Inc. The Alexa Fluor ${ }^{\circledR}$ 546-conjugated goat polyclonal anti-mouse
IgG (H+L) cross-absorbed secondary antibody (A-11030), Alexa Fluor 633-conjugated goat polyclonal anti-rabbit IgG $(\mathrm{H}+\mathrm{L})$ cross-adsorbed secondary antibody (A-21070), and Hoechst 33342 nucleic acid stain (H1399) were purchased from Invitrogen (Thermo Fisher Scientific, Inc.). Coomassie Brilliant Blue R-250 was purchased Biosesang. Other common analytical-grade chemicals and reagents used in this study were commercially available.

Extraction and isolation of I6CA from S. thumbergii. After collection, all algal samples were washed three times with tap water to remove salt, sand and epiphytes attached to the surface, and were carefully rinsed again with fresh water. The samples were stored at $-20^{\circ} \mathrm{C}$ in a medical refrigerator until use.

The frozen algae were lyophilized and homogenized into powder. The powdered S. thumbergii $(2 \mathrm{~kg})$ was extracted three times with $80 \%$ methanol, and the methanol extract was centrifuged at $3,500 \times \mathrm{g}$ for $30 \mathrm{~min}$ at $4^{\circ} \mathrm{C}$ and then filtered with Whatman No. 1 (Whatman Ltd.) filter paper to remove the residue. The filtrate was evaporated at $40^{\circ} \mathrm{C}$ to obtain a methanol extract, which was then suspended in distilled water (DW) and partitioned using chloroform. The chloroform fraction ( $2 \mathrm{~g}$ ) was subjected to silica column chromatography by stepwise elution with a chloroform-methanol solution $(30: 1 \rightarrow 1: 1, \mathrm{v} / \mathrm{v})$ to separate the active fraction $(12.3 \mathrm{mg})$ in chloroform fraction. Silica gel (230-400 mesh) was packed in a glass column (Pyrex, 300x38 mm, Corning Inc.) and a flow of solvent by gravity was allowed during the purification.

The active fractions were further separated by a Sephadex LH-20 column saturated with $100 \%$ methanol. Next, the active compounds were purified by reversed-phase high performance liquid chromatography (HPLC) using a Waters HPLC system (Alliance 2690; Waters Corporation) equipped with a Waters 996 photodiode array detector and a C18 column (J'sphere ODSH80, 250x4.6 mm, $4 \mu \mathrm{m}$; YMC) by stepwise elution with methanol-water gradient (ultraviolet absorbance detection wavelength, $296 \mathrm{~nm}$; flow rate, $1 \mathrm{ml} / \mathrm{min}$; injected volume, $30 \mu \mathrm{l})$. The HPLC eluting conditions were as follows: $5-70 \%$ methanol for $40 \mathrm{~min}$ to $100 \%$ methanol for $20 \mathrm{~min}$, followed by $10 \mathrm{~min}$ re-equilibration time of the column. HPLC anlaysis was performed in a room kept at $24 \pm 1^{\circ} \mathrm{C}$.

Finally, the purified compound was identified by comparing their ${ }^{1} \mathrm{H}$ - and ${ }^{13} \mathrm{C}$-nuclear magnetic resonance (NMR) spectra with reported data (36). NMR spectra (data not shown) were recorded on a ZEOL $600 \mathrm{MHz}$ NMR spectrometer (JEOL). The chemical structure of I6CA isolated from $S$. thunbergii is shown in Fig. 1. For cell culture experiments, I6CA was dissolved in DMSO, and the final concentration of DMSO in culture medium was adjusted to $\sim 0.01 \%$.

Cell culture. HT1080 cells were routinely cultured in complex medium (DMEM supplemented with $10 \%$ heat-inactivated FBS and $1 \%$ penicillin/streptomycin/amphotericin). Cultures were maintained at $37^{\circ} \mathrm{C}, 5 \% \mathrm{CO}_{2}$ in a humidified atmosphere. The cells were subcultured every 3 days using trypsin-EDTA for $3 \mathrm{~min}$ for cell detachment.

Cell viability assay. HT1080 cells were seeded in a 96-well plate at a density of $10^{4}$ cells/well in $100 \mu \mathrm{l}$ of complete medium. The next day, HT1080 cells were treated, in the absence or 


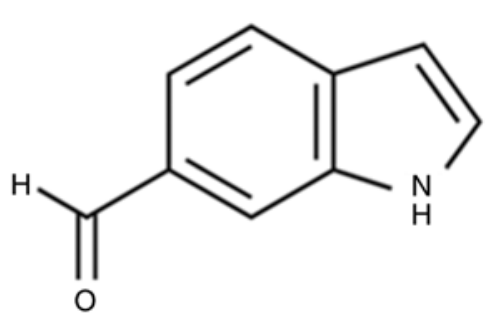

Figure 1. Chemical structure of indole-6-carboxaldehyde.

presence of serum, with increasing concentrations of I6CA $(100,200$ and $400 \mu \mathrm{M})$ in the presence or absence of PMA $(10 \mathrm{ng} / \mathrm{ml})$ at $37^{\circ} \mathrm{C}$. After $24 \mathrm{~h}$ of incubation, $20 \mu \mathrm{l}$ of MTT stock solution ( $1 \mathrm{mg} / \mathrm{ml}$ in PBS) was added to each well. After $2 \mathrm{~h}$ of incubation at $37^{\circ} \mathrm{C}$, the supernatant was removed, and in each well, the formazan crystals were dissolved in $100 \mu \mathrm{l}$ of DMSO. Then, the absorbance was measured at $540 \mathrm{~nm}$ using a Powerwave XS2 microplate reader (BioTek Instruments, Inc.). The relative cell viability was calculated based on the quantity of MTT converted to formazan by the untreated and PMA only-treated cells (100\% viability). The data are expressed as the mean percentage of the viable cells \pm standard deviation of triplicate experiments.

Analysis of MMP-9 gelatinolytic activity by gelatin zymography. The gelatinolytic activity of MMP-9, secreted from HT1080 cells, was determined by gelatin zymography (37-39). HT1080 cells grown in 6-well plate at a density of $10^{5}$ cells/well in $2 \mathrm{ml}$ of complete medium were treated with I6CA $(100,200$ and $400 \mu \mathrm{M})$ in serum-free medium in the presence or absence of PMA $(10 \mathrm{ng} / \mathrm{ml})$ for $24 \mathrm{~h}$ at $37^{\circ} \mathrm{C}$. Cell culture supernatants were collected and their protein contents were measured using a bicinchoninic assay (BCA) protein assay kit (Thermo Fisher Scientific, Inc.) with a standard curve of a range of bovine serum albumin concentrations in DW $(0-1 \mathrm{mg} / \mathrm{ml}$; Thermo Fisher Scientific, Inc.). $20 \mu l$ of cell culture supernatants were subjected to electrophoresis on $10 \%$ SDS-polyacrylamide gels containing $0.25 \%$ gelatin. The gel was washed in $2.5 \%$ Triton $\mathrm{X}-100$ at room temperature to remove SDS and then incubated overnight at $37^{\circ} \mathrm{C}$ in developing buffer $(50 \mathrm{mM}$ Tris- $\mathrm{HCl}$ at $\mathrm{pH} 7.5,200 \mathrm{mM} \mathrm{NaCl}, 5 \mathrm{mM} \mathrm{CaCl}{ }_{2} \cdot 2 \mathrm{H}_{2} \mathrm{O}$, and $0.02 \%$ Brij-35). Finally, the gel was stained at room temperature with Coomassie Blue staining solution (1\% Coomassie Brilliant Blue R-250, 45\% methanol, and 10\% acetic acid) for $30 \mathrm{~min}$ and destained using the same solution without dye. Negative staining (clear bands against a blue background) indicated proteolysis and, therefore, gelatinolytic activity. The MMP-9 gelatinolytic activity was quantified by measuring the band intensities using ImageJ 1.8.0. software (National Institutes of Health). The normalization of loading protein was conducted via electrophoresis with $10 \%$ SDS-polyacrylamide gels after which Coomassie staining to analyze the amount of total loading protein.

Western blot analysis. HT1080 cells were lysed for $30 \mathrm{~min}$ in lysis buffer (20 mM Tris- $\mathrm{HCl}$ at $\mathrm{pH}$ 7.4, $5 \mathrm{mM}$ EDTA, $10 \mathrm{mM}$ $\mathrm{Na}_{4} \mathrm{P}_{2} \mathrm{O}_{7}, 100 \mathrm{mM} \mathrm{NaF}, 2 \mathrm{mM} \mathrm{Na} \mathrm{VO}_{4}, 1 \% \mathrm{NP}-40,10 \mathrm{mg} / \mathrm{ml}$ aprotinin, $10 \mathrm{mg} / \mathrm{ml}$ leupeptin, and $1 \mathrm{mM} \mathrm{PMSF}$ ) and then cell debris was removed by centrifugation for $15 \mathrm{~min}$ at $16,000 \mathrm{x} \mathrm{g}$, $4^{\circ} \mathrm{C}$. The protein concentration of the cell lysates was determined using a BCA protein assay kit. Next, $30 \mu \mathrm{g}$ of proteins were separated by electrophoresis using 10\% SDS-PAGE and transferred onto an Amersham Protran Premium $0.45 \mu \mathrm{m}$ nitrocellulose blotting membrane (GE Healthcare Life Sciences). The membrane was blocked for $2 \mathrm{~h}$ at room temperature with $5 \%$ nonfat dry milk in TBS-T $(25 \mathrm{mM}$ Tris- $\mathrm{HCl}$ at $\mathrm{pH} 7.4,137 \mathrm{mM} \mathrm{NaCl}, 2.65 \mathrm{mM} \mathrm{KCl}, 0.05 \%$ Tween-20) and then incubated for $24 \mathrm{~h}$ at $4{ }^{\circ} \mathrm{C}$ with primary antibodies (1:1,000 dilution). After washing with TBS-T, the membrane was incubated for $2 \mathrm{~h}$ at room temperature with secondary antibody (1:5,000 dilution). The bands were visualized using a CAS-400SM Davinch-Chemi image ${ }^{\mathrm{TM}}$ system (Davinch-K Co. Ltd.).

Immunofluorescence staining and confocal microscopy. HT1080 cells were seeded onto a sterilized 24x24 mm, thickness No. 1 Deckglaser microscope cover glass (Paul Marienfel $\mathrm{GmbH} \& \mathrm{Co} . \mathrm{KG})$. The cover glass was then transferred into a $5 \mathrm{~cm}$ cell culture dish, and the cells were treated for $30 \mathrm{~min}$ at $37^{\circ} \mathrm{C}$ with I6CA in the presence or absence of PMA $(10 \mathrm{ng} / \mathrm{ml})$. For immunofluorescence staining, the cells were washed three times with PBS and fixed for $20 \mathrm{~min}$ at room temperature with cold $100 \%$ methanol. After removing the methanol and washing three times with PBS, the fixed cells were permeabilized for $20 \mathrm{~min}$ at room temperature with $0.5 \%$ Tween-20 in PBS. Subsequently, the permeabilized cells were incubated overnight at $4^{\circ} \mathrm{C}$ with a mouse anti-NF- $\kappa \mathrm{B}$ (p65) primary antibody (1:200 diluted in TBS-T). Cells were washed three times with TBS-T and incubated for $2 \mathrm{~h}$ at $4^{\circ} \mathrm{C}$ with an Alexa Fluor 546-conjugated goat polyclonal anti-mouse IgG $(\mathrm{H}+\mathrm{L})$ cross-absorbed secondary antibody. Finally, the nuclei were counterstained with Hoechst $33342(20 \mathrm{ng} / \mathrm{ml}$ in PBS) for $5 \mathrm{~min}$ at room temperature. The cells were observed under an LSM 700 confocal microscope (Carl Zeiss AG) using a x40 water immersion objective lens. Images were acquired and processed using the ProgRes CapturePro 2.10.0.1 software (Carl Zeiss AG). Pseudo-colors were applied to the images using ImageJ 1.8.0 software, and NF- $\kappa$ B p65 and nuclei were depicted in red and blue, respectively.

Statistical analysis. All quantitative data are presented in as the mean \pm standard deviation of at least three independent experiments that were conducted using fresh reagents. The statistical significance of the differences observed between groups was assessed by analysis of variance, followed by Duncan's multiple range test. All statistical analyses were performed using the SPSS Statistics 12.0 software (SPSS, Inc.). $\mathrm{P}<0.05$ was considered to indicate a statistically significant difference.

\section{Results}

I6CA does not affect the viability of HT1080 cells. We first assessed the cytotoxicity of I6CA purified from $S$. thunbergii extract using an MTT assay. HT1080 cells were treated for $24 \mathrm{~h}$ with increasing concentrations of I6CA in the presence or absence of PMA and serum. Following the MTT assay, we found no evidence of a cytotoxic effect of I6CA and PMA on HT1080 cells, even at the highest concentration of $400 \mu \mathrm{M}$ 
(Fig. 2). Therefore, it was concluded that these concentrations had no impact on cell viability and could be used to conduct subsequent experiments.

I6CA inhibits MMP-9 secretion and expression in HT1080 cells. Next, we examined the inhibitory effects of I6CA on the secretion and protein expression of MMP-9 in HT1080 cells. Using gelatin zymography, we assessed the gelatinolytic activity of MMP-9 in the cell culture supernatant of PMA-stimulated HT1080 cells. Notably, we reported that I6CA inhibited the gelatinolytic activity of MMP-9 in a dose-dependent manner (Fig. 3A). To determine whether I6CA inhibited MMP-9 expression, we performed western blot analysis. Our data demonstrated that the expression levels of MMP-9 exhibited a similar trend to the gelatinolytic activity in the cell culture supernatant (Fig. 3B).

I6CA suppresses mitogen-activated protein kinases (MAPKs) activation in PMA-stimulated HT1080 cells. To investigate the mechanism mediating the inhibition of MMP-9 expression by I6CA, we used western blotting to analyze whether I6CA could regulate the activation of MAPKs in PMA-stimulated HT1080 cells. MAPK activation is mediated by phosphorylation (8). As shown in Fig. 4A, the phosphorylation of the three MAPKs, JNK, ERK and p38 MAPK, was significantly promoted in PMA-stimulated HT1080 cells, compared with in untreated cells. Of note, I6CA treatment significantly suppressed the phosphorylation of JNK and ERK, but not that of p38 MAPK, in response to PMA stimulation.

I6CA inhibits I $\kappa B \alpha$ degradation and prevents $N F-\kappa B$ nuclear translocation in PMA-stimulated HT1080 cells. We examined whether I6CA decreases nuclear translocation of the NF- $\kappa \mathrm{B}$ p65 subunit. As presented in Fig. 4B, western blotting was conducted to analyze the phosphorylation and degradation of $I \kappa B \alpha$, an essential step in the nuclear translocation of NF- $\kappa B$ p65 subunit (10). We determined that PMA stimulation induced the phosphorylation and degradation of IкB $\alpha$, and NF- $\mathrm{BB}$ nuclear translocation in HT1080 cells, whereas I6CA treatment suppressed these effects induced by PMA. To confirm these results, we directly monitored the nuclear translocation of the NF- $\mathrm{kB}$ p65 subunit using immunofluorescence staining and confocal microscopy. When compared with untreated cells, the amount of NF- $\kappa \mathrm{B}$ p65 detected in the nuclei of HT1080 cells increased following PMA stimulation (Fig. 5). Conversely, I6CA inhibited the nuclear translocation of NF- $\kappa \mathrm{B}$, as indicated by a reduced level of NF- $\mathrm{kB}$ p65 detected in the nuclei of HT1080 cells treated with both I6CA and PMA.

\section{Discussion}

The incidence of cancer-associated mortality is steadily increasing, and tumor metastasis, the formation of secondary tumors in distant organs, constitutes the leading cause of these deaths $(40,41)$. Tumor metastasis is a fundamental property of malignant cells and occurs via a series of sequential events that, in the long term, involves the migration and invasion of neighboring tissues, tumor cell intravasation and survival in the circulation system (blood and lymph), and extravasation and
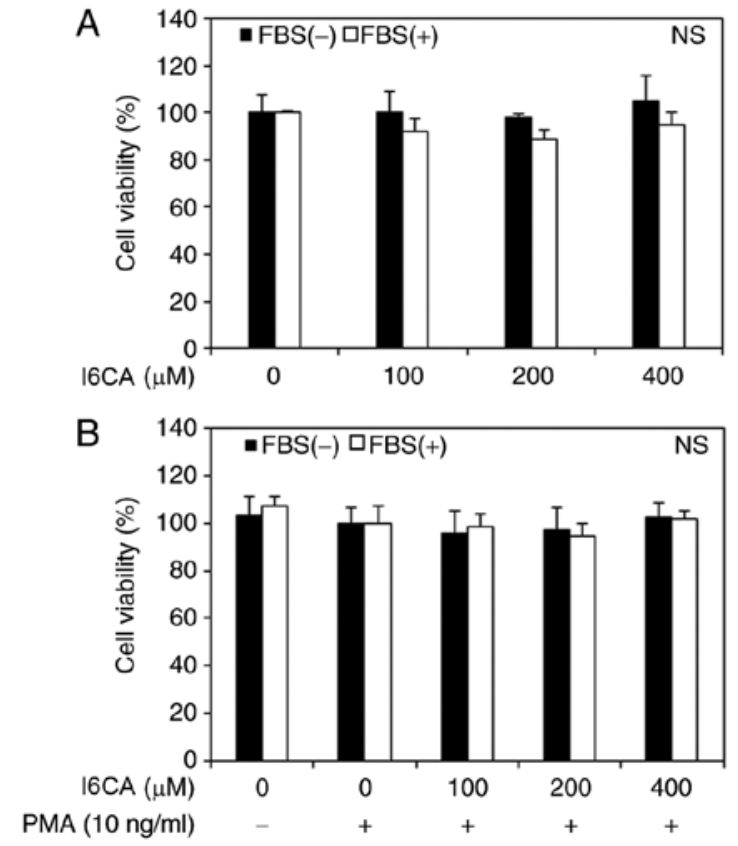

Figure 2. Effects of I6CA on the cell viability of HT1080 cells. The effects of I6CA on HT1080 cell viability (A) with and (B) without PMA-stimulation. N.S., not significant; I6CA, indole-6-carboxaldehyde; PMA, phorbol 12-my ristate 13 -acetate.

proliferation to form secondary tumors in distant organs (42). Tumor cells must degrade the ECM to migrate and invade surrounding tissues and organs; the suppression of ECM degradation is a crucial step in the prevention of tumor metastasis (1). It is widely recognized that MMP-2 and MMP-9 can degrade various components of the ECM and, therefore, are vital regulators of ECM degradation $(43,44)$. With increasing interest in exploring the applications of medicinal substances extracted from plants and other organisms, various compounds have been evaluated for their potential effects as inhibitors of MMP-2 and MMP-9 activities (45-47).

Indole derivatives extracted from various natural resources, including marine algae, have attracted increasing attention, and numerous studies have investigated their biological effects (29-32). Among indole derivatives, a recent study has shown that I6CA could inhibit obesity-related adipogenesis (26); however, the analysis of the biological effects of I6CA remains limited. Therefore, we purified I6CA from $S$. thunbergii for further investigation, focusing on its potential effects as an inhibitor of MMP-9, and the underlying mechanisms. In this report, we presented data indicating that I6CA significantly inhibited MMP-9 secretion and expression in PMA-stimulated HT1080 cells. Comparing the observed inhibitory effect of I6CA on MMP-9 with those reported for other bioactive compounds, we noted that bisphosphonates, carboxylated chitooligosaccharides, various cardiovascular drugs and flavonoids were less potent than I6CA purified from $S$. thunbergii $(1,48-50)$. However, the methanol extract of the red alga Corallina pilulifera appeared to be a more potent inhibitor of MMP-9 than I6CA (51).

The MAPK and NF- $\kappa$ B pathways are generally recognized for their role in the regulation of various physiological processes, including cell proliferation, apoptosis 


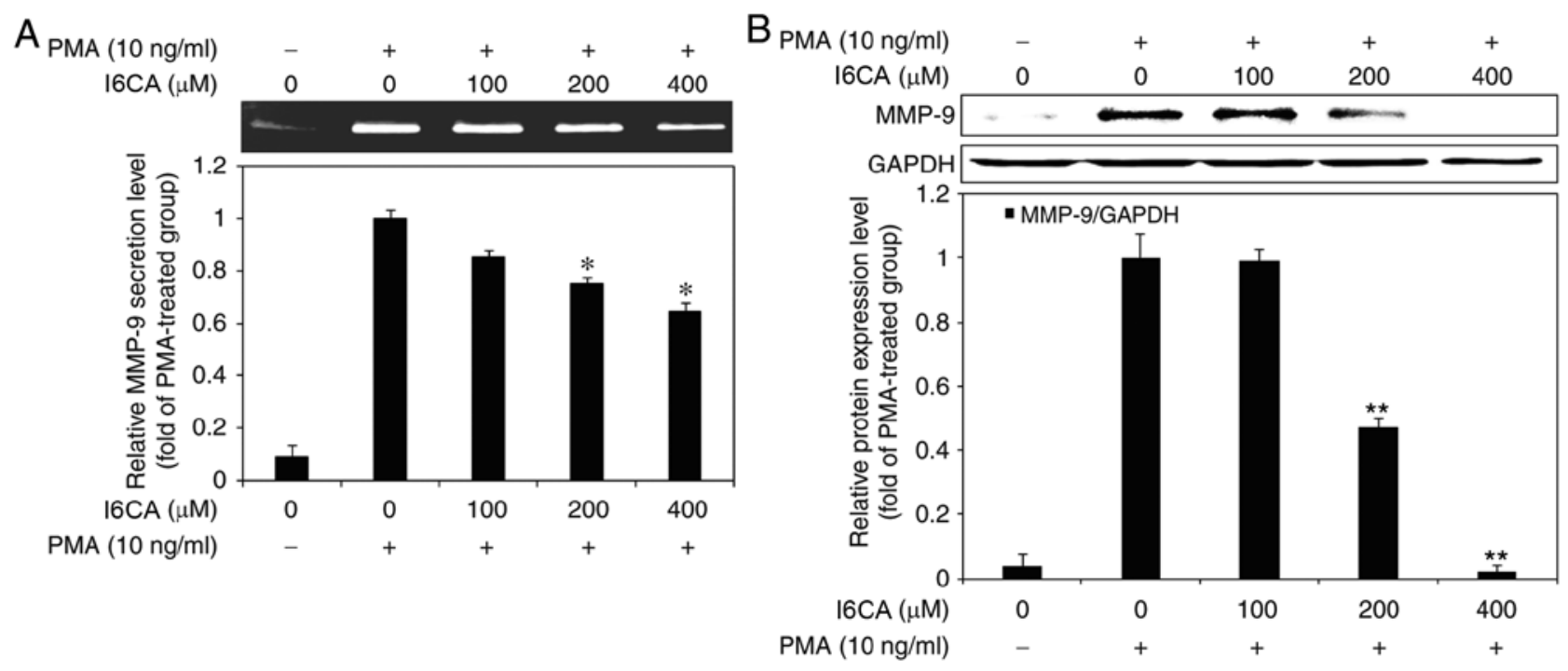

Figure 3. I6CA inhibits MMP-9 secretion and protein expression in PMA-stimulated HT1080 cells. Effects of I6CA on (A) PMA-induced MMP-9 secretion and (B) MMP-9 protein expression in PMA-stimulated HT1080 cells using gelatin zymography and western blotting, respectively. The ratio of densities of the MMP-9 secretion and protein expression bands were used to determine the gelatinolytic activity and relative expression of the MMP-9 protein, respectively. The data are normalized against the ratio calculated for PMA-stimulated HT1080 cells (arbitrarily set to 1-fold). All data are presented as the mean values \pm standard deviation of triplicate experiments. ${ }^{*} \mathrm{P}<0.05$ and ${ }^{* *} \mathrm{P}<0.01$ vs. PMA-stimulated HT1080 cells. I6CA, indole-6-carboxaldehyde; MMP-9, matrix metalloproteinase-9; PMA, phorbol 12-myristate 13-acetate.
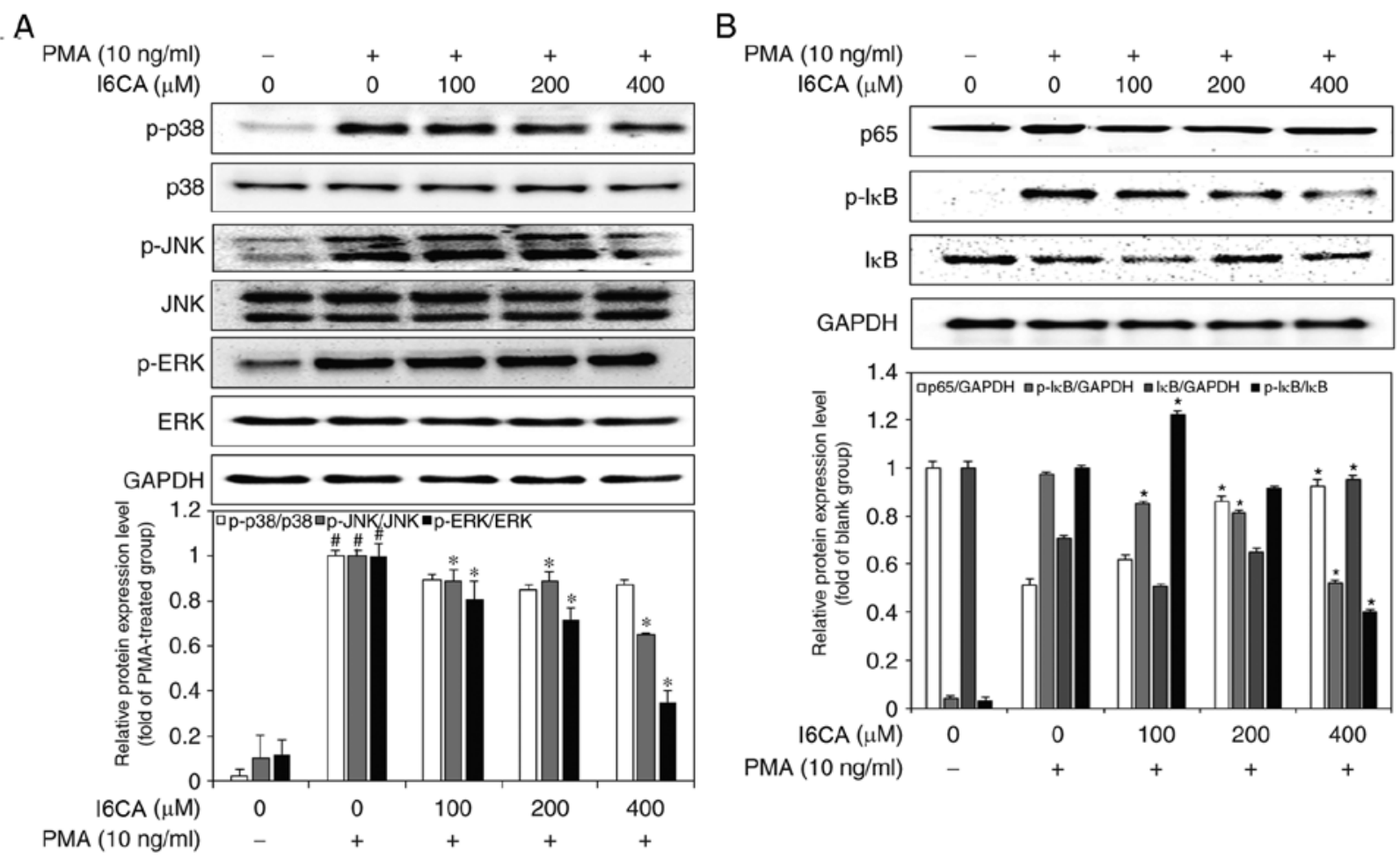

Figure 4. Inhibitory effects of I6CA on MMP-9-related signaling pathway. Effects of I6CA on phosphorylation of three members of the MAPK family,

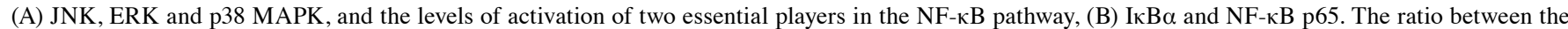
densities of the bands corresponding to the proteins of interest and loading control was used to determine their relative expression. The expression data was normalized against the ratio calculated for PMA-stimulated HT1080 cells (arbitrarily set to 1-fold). All data are presented as the mean values \pm standard deviation of triplicate experiments. " $\mathrm{P}<0.05$ vs. PMA-stimulated HT1080 cells. ${ }^{~} \mathrm{P}<0.05$ vs. un-stimulated HT1080 cells. ERK, extracellular signal-regulated kinase; I6CA, indole-6-carboxaldehyde; MMP-9, matrix metalloproteinase-9; IкB $\alpha$, inhibitor of $\kappa \mathrm{B} \alpha$; JNK, c-Jun N-terminal kinase; p, phosphorylated; PMA, phorbol 12-myristate 13-acetate.

and invasion $(3,7,52)$. According to previous studies, MAPK and NF- $\kappa \mathrm{B}$ pathways are known to promote MMP-9 expression in PMA-stimulated HT1080 cells $(42,53)$. The MAPK pathways involve the phosphorylation and subsequent activation of MAPK family members, including JNK, ERK, and p38 MAPK (54). In the NF- $\kappa B$ pathway, I $\kappa \mathrm{B} \alpha$ binds and 


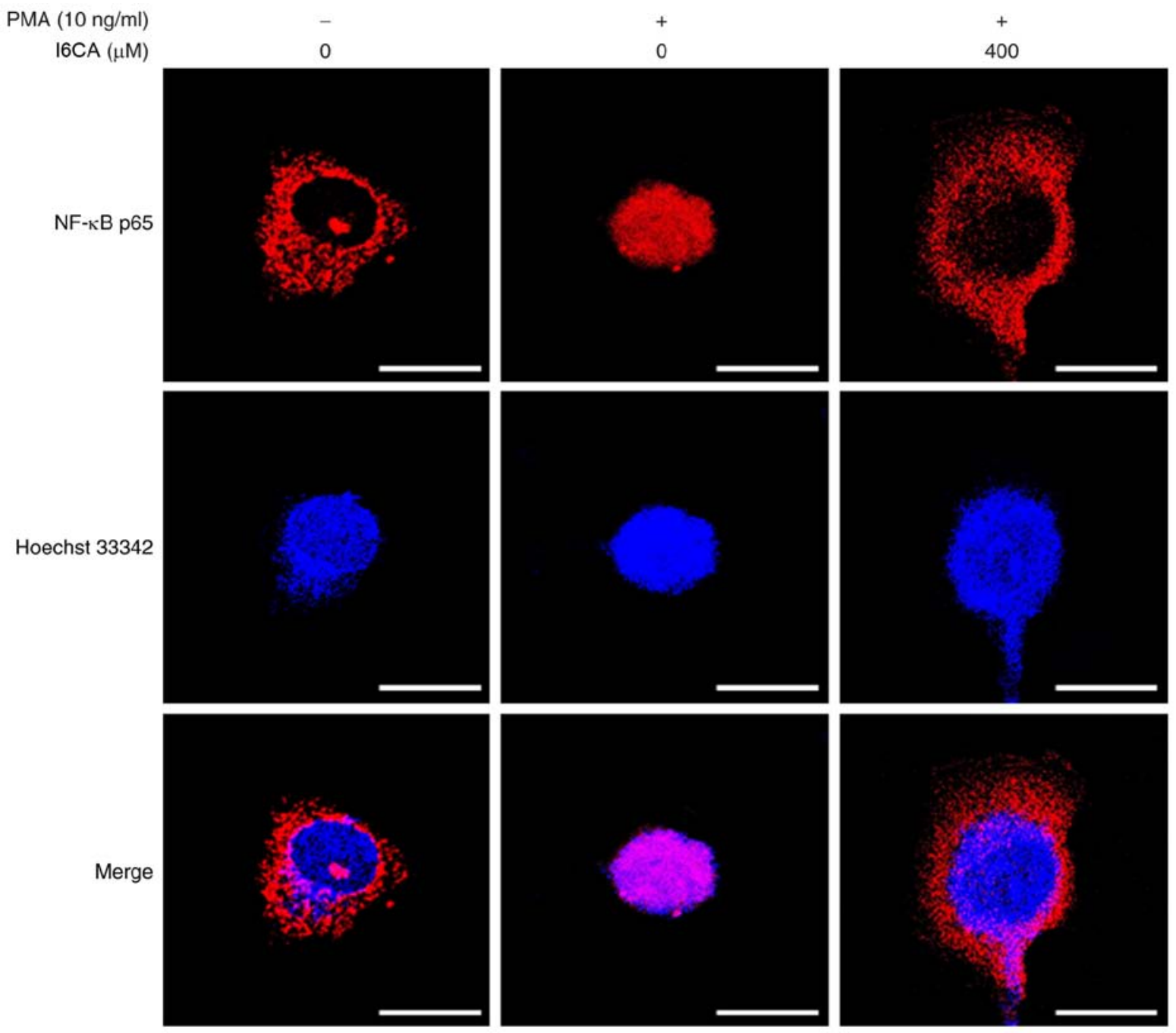

Figure 5. I6CA inhibits NF-kB p65 nuclear translocation. The conditions were comprised no treatment, cells treated with $10 \mathrm{ng} / \mathrm{ml} \mathrm{PMA}$ for $30 \mathrm{~min}$, and the combined treatment of cells with $400 \mu \mathrm{M}$ I6CA and $10 \mathrm{ng} / \mathrm{ml} \mathrm{PMA}$. Red and blue indicated NF- $\kappa \mathrm{B}$ cellular distribution and the position of the nucleus,

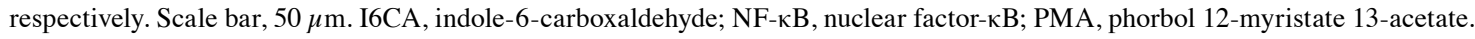

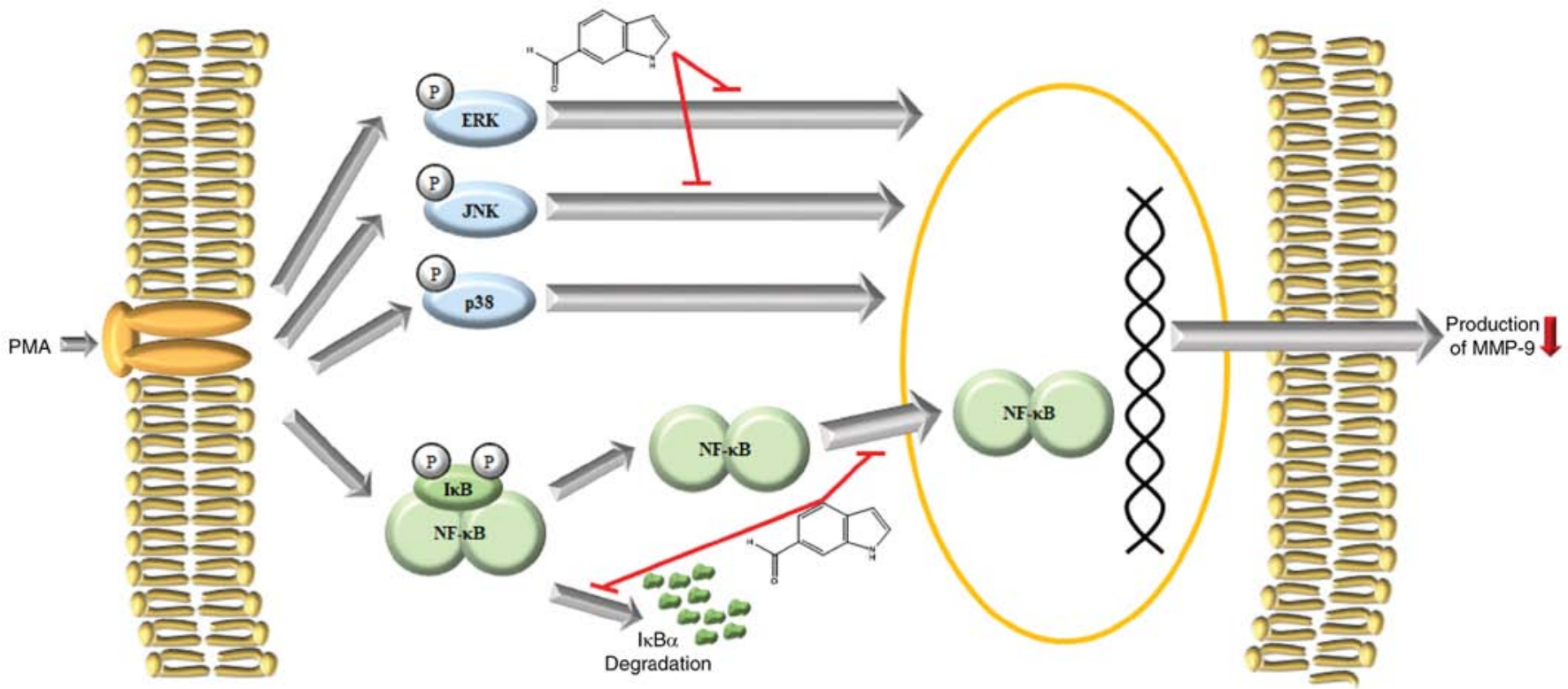

Figure 6. Schematic diagram of the mechanism underlying the inhibitory effects of indole-6-carboxaldehyde on MMP-9 in PMA-stimulated HT1080 cells. ERK, extracellular signal-regulated kinase; I $\mathrm{B} \alpha$, inhibitor of $\kappa \mathrm{B} \alpha$; JNK, c-Jun N-terminal kinase; MMP-9, matrix metalloproteinase-9; NF- $\kappa \mathrm{B}$, nuclear factor- $\mathrm{KB}$; p, phosphorylated; PMA, phorbol 12-myristate 13-acetate. 
retains in the cytosol the inactivated form of the canonical p65/p50 heterodimer, which is activated and translocates to the nucleus upon $\mathrm{I} \kappa \mathrm{B} \alpha$ phosphorylation, ubiquitination and degradation (55-58). In previous studies, PMA has been shown to activate the MAPK and NF- $\kappa$ B pathways in HT1080 cells $(7,8,59-61)$. Therefore, the activation state of the MAPK and NF- $\kappa \mathrm{B}$ pathways is often assessed to analyze the mechanism of regulation of MMP-9 expression $(8,62)$. To unravel the mechanisms of MMP-9 inhibition by I6CA, we examined the activation state of the MAPK and NF- $\kappa \mathrm{B}$ pathways in PMA-stimulated HT1080 cells. Our results indicated that I6CA suppressed the phosphorylation of JNK and ERK, but not that of p38 MAPK, in response to PMA stimulation. In addition, I6CA inhibited the phosphorylation and degradation of $\mathrm{I} \kappa \mathrm{B} \alpha$, and $\mathrm{NF}-\kappa \mathrm{B}$ p65 nuclear translocation in PMA-stimulated HT1080 cells. Previous studies reported the MMP inhibitory effects of various bioactive compounds, such as sulfated polysaccharides and polyphenolic compounds isolated from brown algae (63-65). Based on our findings, we proposed that I6CA, an indole derivative isolated from a brown alga, is a potent MMP-9 inhibitor that acts via the suppression of the MAPK and NF- $\kappa B$ pathways.

In conclusion, we demonstrated that I6CA purified from $S$. thunbergii significantly inhibited the secretion and protein expression of MMP-9 in PMA-stimulated HT1080 cells. These effects were determined to be mediated via the suppression of phosphorylation and activation of JNK and ERK, I $\kappa \mathrm{B} \alpha$ phosphorylation and degradation, and NF- $\kappa \mathrm{B}$ p 65 nuclear translocation (Fig. 6). These findings may further our understanding of the mechanism of action of I6CA in the inhibition of MMP-9. Of note, we investigated only the inhibitory effects of I6CA on MMP-9. Therefore, we plan to perform in vivo experiments in the future to verify whether I6CA inhibits ECM degradation through MMP-9 inhibition, suppressing metastasis.

\section{Acknowledgements}

Not applicable.

\section{Funding}

This research was supported by a research grant from the Marine Biotechnology Program (grant. no. 20150220) of the Ministry of Oceans and Fisheries of Republic of Korea and partially supported by a research grant from the Korea Institute of Ocean Science and Technology (grant. no. PE99722).

\section{Availability of data and materials}

The datasets used and/or analyzed in the present study are available from the corresponding author on reasonable request.

\section{Authors' contributions}

THK, SJH and SCK performed the experiments. SJH extracted and isolated indol-6-carboxaldehyde. MY, WSP, IWC and WKJ conceived and designed the study. All authors have reviewed and approved the final version of the manuscript.

\section{Ethics approval and consent to participate}

Not applicable.

\section{Patient consent for publication}

Not applicable.

\section{Competing interests}

The authors declare that they have no competing interests.

\section{References}

1. Rajapakse N, Kim MM, Mendis E, Huang R and Kim SK: Carboxylated chitooligosaccharides (CCOS) inhibit MMP-9 expression in human fibrosarcoma cells via down-regulation of AP-1. Biochim Biophys Acta 1760: 1780-1788, 2006.

2. Konttinen YT, Ainola M, Valleala H, Ma J, Ida H, Mandelin J, Kinne RW, Santavirta S, Sorsa T, López-Otín C and Takagi M: Analysis of 16 different matrix metalloproteinases (MMP-1 to MMP-20) in the synovial membrane: Different profiles in trauma and rheumatoid arthritis. Ann Rheum Dis 58: 691-697, 1999.

3. Nguyen VT, Qian ZJ and Jung WK: Abalone Haliotis discus hannai intestine digests with different molecule weights inhibit MMP-2 and MMP-9 expression in human fibrosarcoma cells. Fish Aquat Sci 15: 137-143, 2012.

4. Kessenbrock K, Wang CY and Werb Z: Matrix metalloproteinases in stem cell regulation and cancer. Matrix Biol 44-46: 184-190, 2015.

5. Brown GT and Murray GI: Current mechanistic insights into the roles of matrix metalloproteinases in tumour invasion and metastasis. J Pathol 237: 273-281, 2015.

6. Bae WY, Choi JS, Kim JE, Park C and Jeong JW: Zingerone suppresses angiogenesis via inhibition of matrix metalloproteinases during tumor development. Oncotarget 7: 47232-47241, 2016.

7. Nguyen VT, Qian ZJ, Ryu B, Kim KN, Kim D, Kim YM, Jeon YJ, Park WS, Choi IW, Kim GH, et al: Matrix metalloproteinases (MMPs) inhibitory effects of an octameric oligopeptide isolated from abalone Haliotis discus hannai. Food Chem 141: 503-509, 2013.

8. Nguyen VT, Qian ZJ, Lee B, Heo SJ, Kim KN, Jeon YJ, Park WS, Choi WII, CH J, Ko SC, et al: Fucoxanthin derivatives from Sargassum siliquastrum inhibit matrix metalloproteinases by suppressing NF- $\mathrm{kB}$ and MAPKs in human fibrosarcoma cells. Algae 29: 355-366, 2014.

9. Kim YS, Kang HR, Jang SW and Ko JS: Celastrol inhibits breast cancer cell invasion via suppression of NF-kB-mediated matrix metalloproteinase-9 expression. Cell Physiol Biochem 28: 175-184, 2011.

10. Roomi MW, Monterrey JC, Kalinovsky T, Rath $M$ and Niedzwiecki A: In vitro modulation of MMP-2 and MMP-9 in human cervical and ovarian cancer cell lines by cytokines, inducers and inhibitors. Oncol Rep 23: 605-614, 2010.

11. Elewa MA, Al-Gayyar MM, Schaalan MF, Abd El Galil KH, Ebrahim MA and El-Shishtawy MM: Hepatoprotective and anti-tumor effects of targeting MMP-9 in hepatocellular carcinoma and its relation to vascular invasion markers. Clin Exp Metastasis 32: 479-493, 2015.

12. Kang H, Jang SW, Park JH and Shim S: Glaucine inhibits breast cancer cell migration and invasion by inhibiting MMP-9 gene expression through the suppression of NF- $\kappa \mathrm{B}$ activation. Mol Cell Biochem 403: 85-94, 2015.

13. Ko SC, Lee M, Lee JH, Lee SH, Lim Y and Jeon YJ: Dieckol, a phlorotannin isolated from a brown seaweed, Ecklonia cava, inhibits adipogenesis through AMP-activated protein kinase (AMPK) activation in 3T3-L1 preadipocytes. Environ Toxicol Pharmacol 36: 1253-1260, 2013.

14. Deniaud-Bouët E, Hardouin K, Potin P, Kloareg B and Hervé C: A review about brown algal cell walls and fucose-containing sulfated polysaccharides: Cell wall context, biomedical properties and key research challenges. Carbohydr Polym 175: 395-408, 2017. 
15. Lee SH and Jeon YJ: Anti-diabetic effects of brown algae derived phlorotannins, marine polyphenols through diverse mechanisms. Fitoterapia 86: 129-136, 2013.

16. Jung WK, Heo SJ, Jeon YJ, Lee CM, Park YM, Byun HG, Choi YH, Park SG and Choi IW: Inhibitory effects and molecular mechanism of dieckol isolated from marine brown alga on COX-2 and iNOS in microglial cells. J Agric Food Chem 57: 4439-4446, 2009.

17. Gao X, Lee JR, Park SK, Kim NG and Choi HG: Detrimental effects of sediment on attachment, survival and growth of the brown alga Sargassum thunbergii in early life stages. Phycol Res 67: 77-81, 2019.

18. Ren B, Chen C, Li C, Fu X, You L and Liu RH: Optimization of microwave-assisted extraction of Sargassum thunbergii polysaccharides and its antioxidant and hypoglycemic activities. Carbohydr Polym 173: 192-201, 2017.

19. Kim JA, Karadeniz F, Ahn BN, Kwon MS, Mun OJ, Bae MJ, Seo Y, Kim M, Lee SH, Kim YY, et al: Bioactive quinone derivatives from the marine brown alga Sargassum thunbergii induce anti-adipogenic and pro-osteoblastogenic activities. J Sci Food Agric 96: 783-790, 2016.

20. Jin W, Zhang W, Liu G, Yao J, Shan T, Sun C and Zhang Q: The structure-activity relationship between polysaccharides from Sargassum thunbergii and anti-tumor activity. Int J Biol Macromol 105: 686-692, 2017.

21. Kang JY, Khan MN, Park NH, Cho JY, Lee MC, Fujii H and Hong YK: Antipyretic, analgesic, and anti-inflammatory activities of the seaweed Sargassum fulvellum and Sargassum thunbergii in mice. J Ethnopharmacol 116: 187-190, 2008.

22. Park PJ, Heo SJ, Park EJ, Kim SK, Byun HG, Jeon BT and Jeon YJ: Reactive oxygen scavenging effect of enzymatic extracts from Sargassum thunbergii. J Agric Food Chem 53: 6666-6672, 2005.

23. Ou M, Sun X, Liang J, Liu F, Wang L, Wu X and Tu J: A polysaccharide from Sargassum thunbergii inhibits angiogenesis via downregulating MMP-2 activity and VEGF/HIF-1 $\alpha$ signaling. Int J Biol Macromol 94: 451-458, 2017.

24. Kim JA, Kong CS, Seo YW and Kim SK: Sargassum thunbergii extract inhibits MMP-2 and -9 expressions related with ROS scavenging in HT1080 cells. Food Chem 120: 418-425, 2010.

25. Li YX, Wijesekara I, Li Y and Kim SK: Phlorotannins as bioactive agents from brown algae. Process Biochem 46: 2219-2224, 2011.

26. Kang MC, Ding Y, Kim EA, Choi YK, de Araujo T, Heo SJ and Lee SH: Indole derivatives isolated from brown alga Sargassum thunbergii inhibit adipogenesis through AMPK activation in 3T3-L1 preadipocytes. Mar Drugs 15: 119, 2017.

27. Joung EJ, Gwon WG, Shin T, Jung BM, Choi JS and Kim HR: Anti-inflammatory action of the ethanolic extract from Sargassum serratifolium on lipopolysaccharide-stimulated mouse peritoneal macrophages and identification of active components. J Appl Phycol 29: 563-573, 2017.

28. Kang MC, Lee HG, Choi HD and Jeon YJ: Antioxidant properties of a sulfated polysaccharide isolated from an enzymatic digest of Sargassum thunbergii. Int J Biol Macromol 132: 142-149, 2019.

29. Zhang J, Wang JD, Liu CX, Yuan JH, Wang XJ and Xiang WS: A new prenylated indole derivative from endophytic actinobacteria Streptomyces sp. neau-D50. Nat Prod Res 28: 431-437, 2014.

30. Zhang MZ, Chen Q and Yang GF: A review on recent developments of indole-containing antiviral agents. Eur J Med Chem 89: 421-441, 2015.

31. Patel H, Darji N, Pillai J and Patel B: Recent advance in anti-cancer activity of indole derivatives. Int J Drug Res Tech 2: 225-230, 2017.

32. Longeon A, Copp BR, Quévrain E, Roué M, Kientz B, Cresteil T, Petek S, Debitus C and Bourguet-Kondracki ML: Bioactive indole derivatives from the South Pacific marine sponges Rhopaloeides odorabile and Hyrtios sp. Mar Drugs 9: 879-888, 2011.

33. Simoni D, Romagnoli R, Baruchello R, Rondanin R, Rizzi M, Pavani MG, Alloatti D, Giannini G, Marcellini M, Riccioni T, et al: Novel combretastatin analogues endowed with antitumor activity. J Med Chem 49: 3143-3152, 2006.

34. Bandgar BP, Kinkar SN, Chavan HV, Jalde SS, Shaikh RU and Gacche RN: Synthesis and biological evaluation of asymmetric indole curcumin analogs as potential anti-inflammatory and antioxidant agents. J Enzyme Inhib Med Chem 29: 7-11, 2014.

35. Mandour AH, El-Sawy ER, Shaker KH and Mustafa MA: Synthesis, anti-inflammatory, analgesic and anticonvulsant activities of 1,8-dihydro-1-ary1-8-alkyl pyrazolo (3,4-b) indoles. Acta Pharm 60: 73-88, 2010.
36. Xu GH, Choo SJ, Kim YH, Ryoo IJ, Seok SJ, Ahn JS and Yoo ID: Secondary metabolites of Volvariella bombycina and their inhibitory effects on melanogenesis. J Microbiol Biotechnol 20: 78-81, 2010.

37. Chirumbolo $\mathrm{S}$ and Bjoklund G: Quercetin affecting gelatinases in rat aortas: Some comments. Atherosclerosis 275: 444-445, 2018.

38. Cho HJ, Lee S, Park SJ, Lee YD, Jeong K, Park JH, Lee YS, Kim B, Jeong HS and Kim S: Tumor microenvironment-responsive fluorogenic nanoprobe for ratiometric dual-channel imaging of lymph node metastasis. Colloid Surf B Biointerfaces 179: 9-16, 2019.

39. Panwar P, Butler GS, Jamroz A, Azizi P, Overall CM and Brömme D: Aging-associated modifications of collagen affect its degradation by matrix metalloproteinases. Matrix Biol 65: 30-44, 2018.

40. Heron M and Anderson RN: Changes in the leading cause of death: Recent patterns in heart disease and cancer mortality. NCHS Data Brief: 1-8, 2016.

41. Hanahan D and Weinberg RA: Hallmarks of cancer: The next generation. Cell 144: 646-674, 2011.

42. Chung TW, Choi HJ, Lee JY, Jeong HS, Kim CH, Joo M, Choi JY, Han CW, Kim SY, Choi JS and Ha KT: Marine algal fucoxanthin inhibits the metastatic potential of cancer cells. Biochem Biophys Res Commun 439: 580-585, 2013.

43. Lee SJ, Cho SC, Lee EJ, Kim S, Lee SB, Lim JH, Choi YH, Kim WJ and Moon SK: Interleukin-20 promotes migration of bladder cancer cells through extracellular signal-regulated kinase (ERK)-mediated MMP-9 protein expression leading to nuclear factor $(\mathrm{NF}-\kappa \mathrm{B})$ activation by inducing the up-regulation of p21(WAF1) protein expression. J Biol Chem 288: 5539-5552, 2013.

44. Zhang J, Zhu X, Li H, Li B, Sun L, Xie T, Zhu T, Zhou H and Ye Z: Piperine inhibits proliferation of human osteosarcoma cells via G2/M phase arrest and metastasis by suppressing MMP-2/-9 expression. Int Immunopharmacol 24: 50-58, 2015.

45. Liao YF, Rao YK and Tzeng YM: Aqueous extract of Anisomeles indica and its purified compound exerts anti-metastatic activity through inhibition of NF- $\kappa$ B/AP-1-dependent MMP-9 activation in human breast cancer MCF-7 cells. Food Chem Toxicol 50: 2930-2936, 2012

46. Wang KL, Hsia SM, Chan CJ, Chang FY, Huang CY, Bau DT and Wang PS: Inhibitory effects of isoliquiritigenin on the migration and invasion of human breast cancer cells. Expert Opin Ther Targets 17: 337-349, 2013.

47. Chen YT, Kao CJ, Huang HY, Huang SY, Chene CY, Line YS, Wen ZH and Wang HMD: Astaxanthin reduces MMP expressions, suppresses cancer cell migrations, and triggers apoptotic caspases of in vitro and in vivo models in melanoma. J Func Foods 31: 20-31, 2017.

48. Boissier S, Ferreras M, Peyruchaud O, Magnetto S, Ebetino FH, Colombel M, Delmas P, Delaissé JM and Clézardin P: Bisphosphonates inhibit breast and prostate carcinoma cell invasion, an early event in the formation of bone metastases. Cancer Res 60: 2949-2954, 2000.

49. Kim MH: Flavonoids inhibit VEGF/bFGF-induced angiogenesis in vitro by inhibiting the matrix-degrading proteases. J Cell Biochem 89: 529-538, 2003.

50. Rival Y, Benéteau N, Chapuis V, Taillandier T, Lestienne F, Dupont-Passelaigue E, Patoiseau JF, Colpaert FC and Junquéro D: Cardiovascular drugs inhibit MMP-9 activity from human THP-1 macrophages. DNA Cell Biol 23: 283-292, 2004.

51. Ryu BM, Qian ZJ, Kim MM, Nam KW and Kim SK: Anti-photoaging activity and inhibition of matrix metalloproteinase (MMP) by marine red alga, Corallina pilulifera methanol extract. Radiat Phys Chem 78: 98-105, 2009.

52. Dai Z, Lei P, Xie J and Hu Y: Antitumor effect of resveratrol on chondrosarcoma cells via phosphoinositide 3-kinase/AKT and p38 mitogen-activated protein kinase pathways. Mol Med Rep 12: 3151-3155, 2015.

53. Toufaily C, Charfi C, Annabi B and Annabi B: A role for the cavin-3/matrix metalloproteinase-9 signaling axis in the regulation of PMA-activated human HT1080 fibrosarcoma cell neoplastic phenotype. Cancer Growth Metastasis 7: 43-51, 2014.

54. Im NK, Jang WJ, Jeong CH and Jeong GS: Delphinidin suppresses PMA-induced MMP-9 expression by blocking the NF- $\kappa B$ activation through MAPK signaling pathways in MCF-7 human breast carcinoma cells. J Med Food 17: 855-861, 2014

55. Kim YS, Ahn CB and Je JY: Anti-inflammatory action of high molecular weight Mytilus edulis hydrolysates fraction in LPS-induced RAW264.7 macrophage via NF- $\mathrm{BB}$ and MAPK pathways. Food Chem 202: 9-14, 2016. 
56. Rothgiesser KM, Erener S, Waibel S, Lüscher B and Hottiger MO: SIRT2 regulates NF- $\kappa \mathrm{B}$-dependent gene expression through deacetylation of p65 Lys310. J Cell Sci 123: 4251-4258, 2010.

57. Zerfaoui M, Errami Y, Naura AS, Suzuki Y, Kim H, Ju J, Liu T, Hans CP, Kim JG, Abd Elmageed ZY, et al: Poly(ADP-Ribose) polymerase-1 is a determining factor in Crm1-mediated nuclear export and retention of p65 NF-kappa B upon TLR4 stimulation. J Immunol 185: 1894-1902, 2010.

58. Li CW, Xia W, Huo L, Lim SO, Wu Y, Hsu JL, Chao CH, Yamaguchi H, Yang NK, Ding Q, et al: Epithelial-mesenchymal transition induced by TNF- $\alpha$ requires NF- $\kappa \mathrm{B}$-mediated transcriptional upregulation of Twist1. Cancer Res 72: 1290-1300, 2012.

59. Li L, Wang Y, Qi B, Yuan D, Dong S, Guo D, Zhang C and Yu M: Suppression of PMA-induced tumor cell invasion and migration by ginsenoside Rg1 via the inhibition of NF- $\kappa \mathrm{B}$-dependent MMP-9 expression. Oncol Rep 32: 1779-1786, 2014.

60. Kießling MK, Nicolay JP, Schlör T, Klemke CD, Süss D Krammer PH and Gülow K: NRAS mutations in cutaneous T cell lymphoma (CTCL) sensitize tumors towards treatment with the multikinase inhibitor Sorafenib. Oncotarget 8: 45687-45697, 2017.
61. Litvinov IV, Cordeiro B, Fredholm S, Ødum N, Zargham H, Huang Y, Zhou Y, Pehr K, Kupper TS, Woetmann A and Sasseville D: Analysis of STAT4 expression in cutaneous T-cell lymphoma (CTCL) patients and patient-derived cell lines. Cell Cycle 13: 2975-2982, 2014.

62. Kim A, Yim NH, Im M, Jung YP, Kim T and Ma JY: Suppression of the invasive potential of highly malignant tumor cells by KIOM-C, a novel herbal medicine, via inhibition of $N F-\kappa B$ activation and MMP-9 expression. Oncol Rep 31: 287-297, 2014.

63. Alassali A, Cybulska I, Brudecki GP, Farzanah R and Thomsen MH: Methods for upstream extraction and chemical characterization of secondary metabolites from algae biomass. Adv Tech Biol Med 4: 163, 2016.

64. Zorofchian Moghadamtousi S, Karimian H, Khanabdali R, Razavi M, Firoozinia M, Zandi K and Abdul Kadir H: Anticancer and antitumor potential of fucoidan and fucoxanthin, two main metabolites isolated from brown algae. ScientificWorldJournal 2014: 768323, 2014

65. Thomas NV, Manivasagan P and Kim SK: Potential matrix metalloproteinase inhibitors from edible marine algae: A review. Environ Toxicol Pharmacol 37: 1090-1100, 2014. 